\title{
Diary of an lowa Farm Girl: Josephine Edith Brown, 1892-1901
}

edited by Vivian C. Hopkins

At the time Josephine Edith Brown began this diary, September 12, 1892, she was fourteen years old, the fifth of eight children born to William H. Brown and Emma Jane Frazey Brown. Married March 26, 1867, William and Emma Jane moved west from IIlinois to lowa in a covered wagon, June, 1871.' Here they joined the pioneer community of Shelby, enjoyed a happy life together, and prospered, despite privations during the early years. In 1892 the oldest daughter, May Aurilla, was twenty-three; Horace Holt, twenty-one; Louis Arthur, nineteen; William Elbert, seventeen; John Frazey, twelve; Frank LeRoy, ten; and Emma Jane, seven. Robert Brown, William's younger brother, married Ella Frazey, Emma Jane's younger sister. Their sons were Claude and Grant. The two Brown families were very close. There were frequent visits also with cousins Scott and Clara Eshelman, who lived in nearby Persia.

Brown-haired, blue-eyed, petite and slender, Josie was a favorite of her parents-her nickname was Pet. She had an eye for the boys, and was popular with them, but she also treasured her friendships with girls. She loved pretty clothes, parties, and family get-togethers. Since the Methodist Church, to which the family belonged, disapproved of dancing and card-playing, the youngsters diverted themselves with crokinole, charades, musical entertainments, variations of hide-and-seek, husking bees in the fall, sledding and skating in the winter. Buggy rides were a favorite courting pastime.

\footnotetext{
${ }^{1}$ For William's Civil Was service, and their courtship, see my "Soldier of the 92nd Illinois: Letters of William $\mathrm{H}$. Brown and His Fiancee, Emma Jane Frazey," Bulletin of the New York Public Library. LXXIII (Feb., 1969), 114-136.
} 
Josephine's mind was lively and inquiring; at school she excelled in all subjects except mathematics. Through her eyes we see the life of the community -in the fields and barns, the schools and churches. Sad episodes were occasional family quarrels, and funerals-one following a buggy accident. High points were weddings, the fair, and the high school commencement. The diary was recorded in pencil, in two notebooks-one, a composition book, 81/2" $\times 11$ ", the other an account book, 5" x 12". Diary \#1, the compostiton book, covers the period from Sept. 12, 1892, to Sept. 6, 1897, with some omissions. Diary \#2, the account book, covers the period from Jan. 1, 1894, to Feb. 17, 1901, with some omissions. Some overlapping in Sept. and Oct., 1896, is indicated in the text.

The manuscript has been supplemented by information in $\mathrm{A}$ History of the Shelby, lowa Community from Early Times until its Centennial Year of 1970 (Shelby: The Centennial History Book Committee, 1970), and by communications from Mrs. John Bothwell and Everette Starner, residents of Shelby. *

\section{Diary \#1}

Monday.

I went to school to Shelby this morning. V. G. Durfee is the Professor. I don't like his appearance very well. He has a little black moustache and keeps twirling it in his fingers all the time. When he talks he kind of mumbles his words. May S [utton] was at school too. I set with her. I went over town at noon with May S. and Catherine Potter. We went in to Jones's and they went off without me and never said a word. So I had to walk to school with Lew Benham. They thought they had a good joke on me but I didn't care.

Tuesday.

I went to school again today and took the exam. to see if I could

\footnotetext{
*Editor's note: The diary is not printed here in its entirety due to restrictions of space.
} 
go into the 10th grade. I had Grammar, arith., physiology. Prof. told me this evening that I could go into the tenth grade in that if I wanted to. He said he knew how it was, we forget a thing after we once study it if we do not keep reviewing. I slipped through pretty easy. I had seven questions in Physiology which were pretty hard. 3 sentences in Gram. to analyze and parse, and some examples in arith. in cancellation and fractions to work.

Wednesday.

Went to school. Am in the tenth grade. Have to study Grammar, Arith., Physical Geography, and Rhetoric Lit. Went down town with Mary Schmidt and when we came back we caught up with Daisy Reynolds and all of us went down on the depot platform and pulled up our stockings and Daisy made the arrangements that she was to walk to school with Ed Schmidt and Mary and I might walk with Lew Benham. When those two gentlemen came along they were notified of the arrangements. They complied with them and all was so. Emma Davis came home with us tonight. She is going to make my brown dress.

Thursday.

I did not go to school. I had to stay at home so that Emma could fit my dress. Oh, it is going to be lovely. It is made with a princess skirt, gathered waist, full sleeves, and a little short jacket without sleeves. It will make a nice suit. Miss Austin and Laura came over this evening. Pa and Horace were away all day. There was a race this afternoon between Harry Clapp and Alf Lee, and Mr. Rink and Ed Abbott from Shelby to Harlan. Mr. R. and Ed Abbott were given an hour and twenty-two minutes start. They will walk and the other two ride bicycles.

Friday.

I went to school and also heard that the foot men beat the bicycles three minutes in the race. They said that Harry Clapp gave out and fainted before they got to Corley. If it hadn't been for that I guess the bicycles would've beat. Morrises went away to Nebraska today. That is Jennie, Frank, and Mrs. Morris. The train they went on was very late didn't get here till X. 
Saturday.

Pa went to town today and saw the Prof. He said (Pa did) that we couldn't go to Shelby school any more this year and that Willie and I might start in Monday and go to Miss Austin. Well I don't know as I am going to waste my tears if I don't go to school to Shelby and I shall make up my mind to stand it or lay down.

Pa says I can study the same things here and keep right up with the class if I try but I know it will be different. Shelby did a very poor thing when they exchanged Field for Durfee. I don't like Durfee near as well. I wonder what May S [utton] will say.

Sunday.

Horace and I went over to Pleasant Mound this morning horseback. I rode the pony, Jennie, and he rode Stella. Jennie run away coming back and I got pretty well jolted up, but didn't fall off. May and Willie and Emma went to Persia. Ma, Pa, and John went to Shelby, and took Emma Davis home. Uncle Rob's came up about $12: 30$ and staid till night. Emma wasn't here so I got to play with Grant. We just had a big time.

Monday.

Staid at home. Pa went away this evening to Storm Lake to stay till Sat. Pa said we might go to school to Shelby again if Lou could go in the eleventh grade. He said Willie and I might stay in tenth grade but if L. couldn't go in the eleventh he could quit.

Tuesday.

Well, I went to school today. L. is going in the 11 th so we can go to school. I got myself a Rhetoric book this morning. Boys got some other books this evening. [Epworth] League met tonight. Horace, May, and Willie went. I had the headache.

\section{Wednesday.}

May went to Uncle Rob's tonight and staid all night. Went downtown with Dora Hently today and was tired as a dog tonight.

Thursday.

Went to school. My studies are Gr. and Rhet., Arith., Phys [iology], Geog., and Lit. I borrow Katie Ded's Lit. book. It is Whittier. We have read "Maud Muller" and we read "School Days" 
today, and then we had to write a kind of a story ofit afterwards.

Friday.

Went to school. There was a lecture this afternoon in the highschoolroom, by Prof. Sangerman on Voice Culture. We got permission of the board to have the schoolroom, and he was in our schoolroom before school time this morning talking to Prof. D. and he came again just before recess, and addressed the school. He asked how many of us would like to hear him this afternoon imitate twelve different musical instruments, and also hear him talk of Voice Culture. We held up our hands. He then asked us how many would be willing to pay $\$ 1.00$. We didn't hold up our hands this time and he made a wry face, but he said they had fixed it so that each one might pay 10c. if he wanted to and if he didn't he didn't have to. Ed Best and Walter Linn were the collectors. I didn't give anything, neither did May S[utton]. Prof. S. came this afternoon at two and commenced his lecture at 2:15. Miss Bannerman's and Miss Gates' scholars were there too, besides the other teachers, Misses Smith and Knott. Prof. S. spoke in regard to speaking, reading, and singing. He said that in reading one needed: first-a good pronunciation. Second-Mind and tongue in harmony. Third-a good cultivated voice. He asked how many sounds to the letter $a$. Someone said seven. "Well!" he said, he could never see but five. He gave us five words then: namely, farm, hat, hate, hall, and what.

And another thing he said why some people stutter and stumble and forget their piece in speaking was because their mind and tongue were not in harmony. He said, Speak first and think after. He said some people swallow raw eggs to make their voice clear. Some other people suck licorice. The twelve instruments which he imitated were Clarient, Flute, Tremolo flute, Trumpet, Cornet, French horn, Ophicleide, Double bass Ophicleide, Trombone, Jews harp, Drums. "The Last Rose of Summer" he played on a guitar and accompanied it with clarinet. Of course he didn't look very pretty while he imitated them. He also played "The Hungarian March Polka" and "The Carnival of Venice." He said to "Never give up." He gave us an example of Chinese, Turkish, and Swiss singing. Well, I must not write more tonight.

Saturday. 
May and Horace went to Harlan today. May got three new head-gears: one for herself, one for me, one for Emma. Mine is a light brown sailor to match my dress. Hers is a black one with white velveteen crown. Emma's is a dark blue tam-o-shanter cap. $\mathrm{Pa}$ came home tonight. He's going away tomorrow.

Sunday.

Willie, Horace, Emma and I went to church this morning. I wore my brown dress for the first time. I didn't wear my jacket-it hasn't the gimp on it yet. When we got home from church George S [utton] was here, and after we got commenced to eat dinner, Mr. and Mrs. Boardman came here to dinner. Mr. and Mrs. Fagan came about the middle of the afternoon, and $₫$ r. Mayne and Miss Austin are here this evening. Oh, "It never rains but it pours," here. I took a buggy ride this afternoon with George S. way over past Schoolhouse No. 3. George said he told me last Sun. he was coming over but I don't remember that he did. I remember of him saying he was coming over some Sun., but rdidn't know or didn't hear him say he was coming today. He is still working at Mr. Lawson's. He told me that Renia Gatrost is spunky at him about something and won't speak to him any more. Her sister works at Stevens' now. Oh, yes, Elbert Brown was here this afternoon too. Mr. Howe preached today. He said that if anyone had come to church today with the expectation of hearing a farewell sermon from him would be disappointed, for he never did preach one. He said there might be such a thing as, if he was spared, as him standing in that same pulpit and preaching a farewell sermon, and he would feel foolish to think he had preached one before, but he said it was too much like preaching his own funeral sermon. Franklin will preach next Sun.. Horace took $\mathrm{Pa}$ to the train tonight. He is going to Panora tomorrow.

$$
\begin{gathered}
\# \# \\
\text { Beginning of Diary \#2 }
\end{gathered}
$$

Jan. 1, 1894.

I have begun this New Year's Day to read the Bible. Will read 3 chapters every day and 5 on Sunday. I intend to make this a better year. I will study hard and understandingly in school as I never have. If I do feel disinclined, I will make up my mind and do it. And 
another thing, I will be more sincere in what I think and say. Unselfishness is what makes good manners and shows good breeding. I will think of others and try not to think of myself. There are a ' great many people that I would have think well of me, but I must be worthy of such and I will earn their good will.

Tuesday, Jan. 2.

May went away today. I was late at school, 30 minutes. Got excused. Changed seats today. Myrta B. and I have the back seat on second row.

Wednesday, Jan. 3.

My birthday-sixteen, and am in my seventeenth year. The singing school did not make expenses, so they are going to get up an entertainment, so they are going to have a farce in about a month. They read one over tonight at our place after school.

Thursday, Jan. 4.

Party out to Yongs'. Misses K. and Incges went with Lew Benham, and Gertie S. and Miss Osincup with Lowell Jones. Stella Tucker's birthday. She gave a party. Miss Smith and I went to it. It was kids of about her size. Had a good time.

Friday, Jan. 5.

Came home. It was queer May did not come home too. The Shelby High School Demosthenian Society this afternoon. Constitution and Bylaws approved of.

Saturday, Jan. 6.

At home. $\mathrm{Ma}$ and $\mathrm{Pa}$ went to town this afternoon and got for me a silver thimble for my sixteenth birthday, Wednesday last.

Sunday, Jan. 7.

$\mathrm{H}$ [orace] and I went out to take a buggy ride this afternoon and went over to Suttons'. Ura and Mrs. Slaughter entertained us. Maud was away. Olive S. and the rest of them were out in the kitchen-never came in at all. Stayed about 3/4 of an hour and then came home. We are not going there any more.

I have not read in my Bible any this week. I s'pose that resolution is as good as busted. Well, I've got too much to study anyway. 
Rosa Stevens and her father are going to move to Harlan and keep house together.

Monday, Jan. 8.

Went to school. We elected officers for our Literary Society. Frank Linn, Pres.; Harvey Cutshall, Sec'y; Edith Tate, Vice Pres.; Josie Brown, Treas.: Watson K [inney], Hattie Plum and Edgar Keeney, Executive Committee; Edgar Best and Libbie Walker, two marshals.

Tuesday, Jan. 9.

Miss K. and L. Benham, Gertie S. and L. Jones went to the Swiss Bell Ringers. They said it was pretty good.

Party down to Fred K [inney] 's. Miss Osincup got it up. I went with Ed and Hattie went home from school with them and came back and stayed all night. It was a crokinole party. Just one dozen invited, and enough for four boards.

Thursday, Jan. 11.

We girls are going to have Indian club exercise every week. Prof., our teacher, had our first lesson tonight. Bessie Benham, Bessie Morton, Jessie Laughman and myself. I expect there will be some more, maybe the schoolmarms.

Friday, Jan. 12.

Miss Smith sick, unable to teach. Dr. thought she had the symptoms of scarlet fever, but it is only grippe and tonsillitis.

Came home after school with $\mathrm{Pa}$.

Saturday, Jan. 13.

Tired out all day. Went down to Morrises at night, had a fine time. Played blindman's buff and charades.

Sunday, Jan. 14.

$\mathrm{Ma}$ and $\mathrm{Pa}$ and Willie and Horace went to church this morning.

Emma and the boys and I went out and played "Sheep Out" and "Grunt" this afternoon. I must go to bed.

Monday, Jan. 15.

Will and I went to school. Met Claude coming home. He said the 
school was quarantined, no use for us to go, but we went anyhow. Picked up May Sutton and took her with us up to Miss Gochenour's and then over to school. May and I got out and went in. Prof. and the teachers and Mr. Laughman was there. They all came out on the porch and talked a while. The teachers are going away today. Then we pupils went upstairs with Prof. and talked the thing over and decided to petition the Health Board and School Board to let the High School go on after fumigation. We all signed the petition and Willy Bell is going to take it around and get all the rest to sign it if he can.

$$
\text { \# \# }
$$

May 16, Wednesday, 1895.

Went to town. Got a hat, a $25 \notin$ sailor hat, brown. I can't get along without a brown hat, summer and winter. I will trim this myself. Uncle told me that the committee for arrangements had put me on for a Reading Decoration Day. I hate to speak but s'pose I can't get out of it. I believe Hattie must have told her father to put me on. He was one of the committee, and she spoke last year. Uncle and Mr. Adams were the other two. Took the carpet away today to Mrs. Ostran. I saw her weave some carpet; I think it is very hard work.

\section{Thursday.}

Trimmed my hat. Was going over to visit Will's school, but it looked like rain, so we stayed home. John was going with me.

Friday.

Went to town with $\mathrm{Pa}$ and Louis. Got up to school just at recess. Went home with Hattie after school. May S[utton] wanted me to go with her.

Jessie L. was awfully glad to see me; came down the hall to meet me, kissed me like anything. Ed K[inney] was at home; think he must be lazy or awfully tired. Saw Mr. Rand.

\section{Saturday.}

This afternoon Hattie and I stayed at home alone. Ed wanted to stay, but we drove him off to town; said we would lock him out. Mr. and Mrs. K[inney] went to town, and the hired man stayed out 
of doors all the time. We made some taffy, she studied some, and I finished my book about "Little Fishers and their Nets," which I had commenced last winter once when I was down there. We went to bed in the evening. Hattie studied and looked up the Epworth League lesson for Sunday night. She has to lead. A year ago today was Commencement night. We thot of it and talked about it. So different now. I am glad I am not in school now. There has a great deal happened this year. but I'm glad nothing fatal has been. Sunday the 19th.

Went to Sunday School and church. Frank Allan was our S.S. teacher. Miss S. wasn't there. Went out to Rob's after church. Browns and Kinneys, just the young people. Went to church tonight, Hattie and Will and Louis and I in our buggy, and Claude and Ed in theirs. Horace played smart and caught a ride with Will McLaughlin. I think Hattie didn't like it, altho' she said nothing. Horace ought to be ashamed of himself for treating her so mean. For Louis and Willie might as well be two wall flowers for all anyone will think of them.

Tuesday.

$\mathrm{Pa}$, Horace, and John went to Omaha. Ma could not go 'cause all the rest of the family went. I s'pose she'll always have to stay at home. Makes me mad.

Louis and I went to Epworth League after the folks. John didn't come; he's gone to stay with Fred a day or two.

Mr. Rinks' baby died today. They had it baptized and christened this forenoon. It was a little girl and they wanted a little girl so badly.

Thursday.

Got a letter from Renia Vincent. I think she is going to get married. She said if I was going to come to see her before she got married, I'd better come soon, say next week. So eventually, it must be going to come off soon. I shall have to write to her.

Sunday, Memorial Day.

Went to church. Rev. Carpenter preached. The G.A.R., W.R.C., and S.V. attended in body or bodies. The sermon was about "Heroes." Good-but sounded like ancient history. One thing I thot he might have left out, about one hero who was sentenced to be 
killed and his head and legs cut off and put in different places. The hero said, when told of his sentence regarding the death, "Would that I had flesh enough to be sent to every town in the country." I s'pose it was heroic, but too much so for a sermon. The three thoughts of the sermon were 1) Love of one's country 2) Love for humanity 3) Love of God.

Miss Smith came home with us, stayed till this evening. We took a ride over to Miss Smith's old home. She got some flowers and took home with her, roses, etc.

I stopped tonight and solicited at Morris's and Rob's for the Epworth League ice cream social Tuesday night. Allan had just got home from Council Bluffs, where he has been with a lady friend, Addie Bird, I s'pose. The Shelby News got it out on them. Guess they didn't want anyone to know it.

May 31. Decoration Day.

Went home with May Sutton tonight. Stayed all night. I had quite a time this day.

Friday May 31.

Went to the last day of school today with May Sutton. Mr. Stevenson gave an address to the Seniors. One speaker was selected from each, the Senior and Junior class. Edith Tate gave an address, "Courage, Juniors," and Bessie Morton responded with an address "Farewell, Seniors." It was the saddest last day I ever was to. Miss Plum broke down and the rest of the seniors wept a few tears. I had lost my handkerchief so I didn't dare to weep.

Frank and Jennie and Will and I went to Persia tonight to the Commencement. Frank Morris is the miserablest fool I ever knew. Bet we don't go that way again.

Friday June 7.

Put down carpet in kitchen today. In the morning Rich Willis came up for $\mathrm{Ma}$ and $\mathrm{Pa}$ to go down. Uncle Rob is sick, and they wanted the folks to go down. They went. Pa came home for dinner. Uncle Rob is awful sick, pleura pneumonia.

Saturday.

He is no better. Heard from there twice today. Tonight we and Will and Smith's went up to Fred Lawson's. Roy L. went too. He 
wanted to know if I would be at home tomorrow afternoon. Told him I didn't know, it remained to be seen. Well, I don't know for a fact. He must have wanted to come down.

Sunday the 9th.

It rained last night and this morning. Horace and Will and Emma and I went down, stopped at Uncle's. Claude came out pretty soon. I went in, and no one was downstairs, so I went upstairs. They were all in the south bedroom, Dr., Pa and Ma. Uncle and Aunt. They were trying to fix Uncle's bed. Aunt Ella said, "You better go down, Josie, till we get through here." I did not go in the room at all, and so did not see Uncle. Pa told me to tell Horace and Claude to come up and help them. Then I went down and after a while Willie and Horace and I went to church. Uncle was no better. Dr. said a change would take place the $3 \mathrm{~d}$, the 5 th, and the 9 th day. Today was the 3d. Mamma came home with us; Pa told her she better come and make it seem more like home up here. Ralph and Sanford and Arthur were here when we got home. The day felt sad. I wrote a letter to May and told her how bad Uncle was. Mamma went back to Auntie's tonight. Uncle Rob said he wanted her and Pa to stay till he died or got better.

Uncle Rob died Wed. morning June 12, 1895, at about eight o'clock. Ma and Pa were there. Uncle Dierly and Uncle Frank came, got here just a few minutes after he died. Horace and I went down this afternoon. It seems so terrible to think he is dead, different from what I ever thought of it. It is coming pretty close home. I can't believe it. I saw Uncle and he looked oh! so natural, lying in the bedroom downstairs. Thursday afternoon at 3 o'clock was the funeral. Aunt Molly came with Scott and Clara. It was a G.A.R. funeral. The pallbearers were Hugh Snyder, Fred Keeney, Harry Buckley, Jake Buckley.

His coffin was so nice. It said on the plates. "Our Comrade," "At Rest," "We shall meet again." The funeral was in the yard. Stevenson preached and they had the organ out in the yard. Sylvia played.

June 23, 1895.

About 28 persons was baptized today, Claude and Louis and myself among the number. It means a good deal to be taken into the church. Seems like after people make the promises and vows they 
ought to live better lives. Well, I suppose they try to live just as good a life as they can, for no one can be perfect.

Jan. 1, 1896.

$$
\text { \# \# }
$$

Happy New Year to you, my diary! May the records of this year be happy ones. Indeed I am going to try to make it so. I ironed today. May came home about noon. Mr. Miller (Vet) was here today, killed old Bill and took his hide off. It was too bad to kill him, but better than to have him in his old misery; he was too old. Mr.

Williams is worse today. Tomorrow night is a party at Morrisses, and Friday night there is a spelling school over to Pioneer. I'd like to go to the spelling school, because-Tomorrow is S.S. convention at M.E. church.

Jan. 2.

Mr. George Williams died last night at 2 o'clock. Funeral is to be Saturday. $\mathrm{Pa}$ is one of the pall bearers. The party down at Morrises tonight we did not go to. Horace and I went to Longs' last Friday night; no one else was there. Surely no one will go tonight, as it is so very cold. Besides, it is the last night May will be home, and I did not care to go. We played History cards tonight.

Jan. 3, 1896.

Mamma gave me my new dress, a green henrietta, as fine as silk. May went away to Aurelia today. Horace and I took her to the train. This is my birthday and I am eighteen years of age. One more year and I will pass my last teen never to enter them again except in thoughts. Would that I knew what of pleasure this year might bring forth. I wish I was only wild enough to carry out a scheme I have long had in my mind. Would it be too wild for me, a girl out here among the country? Surely this year will privilege it. I will soon be too old (?) for such fancies. On this scheme seems to hang the balance. Would that I only knew how it could turn out. I will pray to God to give me clearness in my views. In my past experience I can see where many things were for the best that then were very disappointing to me. It is said, "All things work together for good to them that love God."

May went away today. I hate to see her go, but gradually I am 
growing used to parting with her, and I care not so much as last year I did. Why, I wonder? because last year everything ahead seemed a blank without her, and no fun, but this year, Is the prospect better, or what makes the difference? Is my heart stronger? True, we have a prospect for some diversion from the monotony. Even last night while we were at home there gathered at the house of Morris those still young in the houses of Keeney and Long and made all due arrangements for a club of the country young people, with Allan Morris as Pres., Emma Long Vice-Pres., Vera SI., Sec'y. The next meeting is to be here next Wed. evening. It is the club. Ed Keeney stopped here for supper while out on his canvassing rounds. He told of the arrangements.

Jan. 22.

Maud's wedding day. It was a nice day too, for a wedding this time of the year. Warm-cloudy part of the time too. They [Maud Sutton and Robert Mattox] were married at 7:30 by Mr. Aston, Presbyterian minister. About 60 were there. The bride wore a gray woolen dress trimmed with green velvet and green ribbon bows and pearl trimming. It was in a basque with huge leg o' mutton sleeves and a pointed collar of the velvet trimmed with pearl trimming, and it had bows on the skirt. Her hair was waved very prettily indeed and done in a Grecian knot on the top corner of her head. Ah! but she made a sweet bride. She is one year older than he. She is the more enthusiastic of the two. He was dressed in the regulation style. Had his hair curled all over the top of his head. He was sweet enough to kiss. Horace and I had a bet he wouldn't carry out his part first, and I wouldn't carry out mine unless he did. They got many nice presents-two center tables, two clocks, parlor lamp, silver knives and forks and teaspoons and tablespoons. (Morrises and us took them a silver cake dish.) Napkins, towels, silver toothpick holder. mirror and comb case, and two glass tea sets, and a whole lot of other things. The supper was served in what will be their parlor after they get their house all finished. Allan Bell was the waiter. They had pressed chicken, cold pork, salad, slaw pudding, sauce, jelly, celery, four kinds of cake. I got some to take home with me. Must close for tonight and go to sleep.

March 23, 1896.

Began my first term of school, Dist. No. 2. Mr. Lawson, 


\section{Director.}

Had 13 scholars.

May had 14 scholars.

March 25, 1896.

Got my watch Wed. evening. In the evening $\mathrm{Pa}$ came home from town and handed me the watch, and said, "Here is a little package for you." And it was a watch, all scalloped around the edge, and just a little plain place on one side for my name.

Hampden works. Duber case. Stem winding. Stem set. Nickel works. Eleven jeweled.

September 7, 1896.

Began school today-10 scholars. The schoolhouse has had the holes plastered up and Mr. Lawson said this morning when he was there that he would get the schoolhouse papered maybe next Saturday, but I don't s'pose he will. I went down to his house tonight and signed the contract. He had it already made out. Nellie Kinsey is teaching at No. 1, myself at No. 2, Mr. Pritchard at No. 3, Bessie Morton at Glendale, No. 4, Mrs. Hartrofc at No. 5, Wm. Bullock, No. 6, Hattie Plum, No. 7, Hattie Keeney, No. 8.

Had a very good school today, good order, etc. It starts in better than it did last term.

\section{Wednesday.}

Had a letter from Grace Custer. She wants my school for the winter if it isn't taken; sweet girl, would like to know her better; think we could be good friends.

Friday.

Am tired tonight, dreadfully. Was tired Wednesday night, tireder Thursday, and tireder than all tonight. May came up from Neola tonight with Mr. Buckley. She likes her school and her boarding place very well. I know she will have a better year this year than she had last. She boards at Mrs. Killpack's-two other teachers board there.

\section{Oct. 23. [Return to Diary \#1]}

School is out. I gave the children and Mr. L. little souvenirs with their names, my name, and director's name, on them; date and 


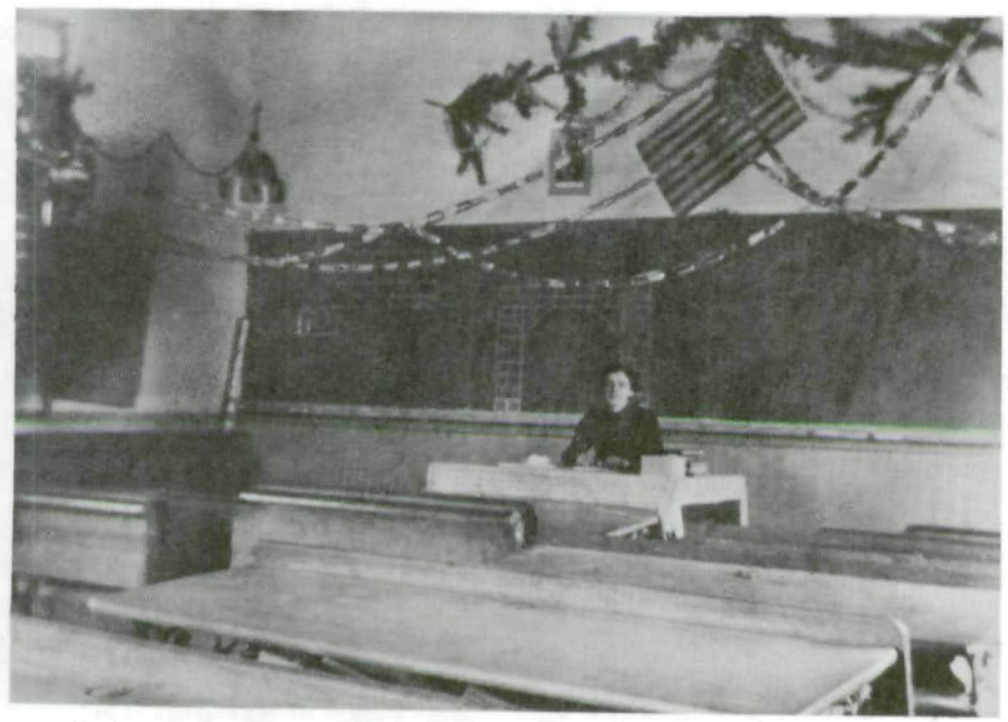

Josephine in her classroom

Courtesy of V. Hopkins

term also. Mamma and Mr. Davis were there, John and Frank. Had a little program. Also I treated them to candied popcorn done up in paper napkins, and the children like it very much; also their report cards they seemed to enjoy, with their \%'s marked on them.

I have enjoyed this term very much, and have done better work than I did last spring, and enjoy it all so well. I don't know if I shall ever teach again or not. Olive Sutton has the winter term.

Nov. 14.

Olive S. began her school today. We went to Harlan today, Mamma and $\mathrm{Pa}$ and Roy and myself. Got my new coat; it is a black boucle cloth. I like it quite well.

Nov. 15 .

Mamma lined and padded my jacket to make it warmer.

Nov. 18.

I went over to Davises today; wore my new jacket. Took some money over to Mr. Jackson, that had been given to $\mathrm{Pa}$ when he was in Harlan. Laura seemed quiet today. Mrs. Davis is quite nice. She had a great deal to say about Walter. Well, it won't do me any good; 
she can save her breath.

Dec. 22.

Uncle Sam came home today from Denver.

Dec. 29.

Went to Epworth League. Blanche Booker came home with me tonight.

Dec. 30.

Went to visit the school today. Mamma went down to Aunt Ella's to see how Claude is. She was going to stay all night, but did not.

Dec. 31.

The M.L.R.C. party was tonight, but we did not go.

Jan. 1, 1897.

Blanche went home and I stayed at Aunt Ella's all night, cooked the meals, washed the dishes, and that is about all I did.

Jan. 3 .

This is my birthday. I am nineteen today. My last teen. Mama gave me a dandy little pair of scissors, and said I would have to sew, but 'tis the bane of my life to sew. I'll do the cutting out, but somebody else will have to sew it up. Alf Leighs' were here for dinner. We had bananas and caramel cake for supper.

I read Timothy's Quest today. It is Emma's Christmas book. Jan. 4, 1897.

I cried tonight. We were downstairs after supper sitting around the table and John was popping corn. We were teasing Louis and pretty soon he gave me a cuff beside the head and I came upstairs and cried and cried all to myself. Big brute he is anyway. Emma came up pretty soon and wanted to know what was the matter. I had been crying. Then Mama came up and talked to me. She is so good and told me I knew what Louis was and mustn't cry about him. She says she prays for him every day of her life, but says she don't know what makes him be so gruff. It did me good to cry, and I told Mama it is so hard to be good, and I can't help from saying 
and thinking the mean things. She says $\mathrm{Pa}$ is so cranky it makes her that way too, but she is trying to be gentle, poor dear Mamma. I didn't know she had to try to be good. I thought the Christian life would get easier after you lived in it a long time.

$$
\text { \# \# }
$$

Although Josephine was usually happy with life on the farm and in the community, the Diary shows a longing for wider horizons, a life of more spice and variety. This longing began to be fulfilled with her admission in 1899 to the Class of 1903 at lowa State College in Ames. Her brother John was also in '03, Roy, in '04. Josephine studied Home Economics, and the boys, Engineering. At Ames Josephine met a classmate, Richard Hopkins, a Civil Engineer. Josephine and Richard were married February 24, 1906.

\section{lowa State College, Ames, lowa}

April 8, 1900.

Went to church and S.S. this morning. Tore a hole in sleeve of my waist. Took a walk this afternoon out in the park. Did not get back for supper. Went to prayer meeting tonight, then to the library. Read Kipling's “Wee Willie Winkie," "Baa Baa, Black Sheep," “'His Majesty the King."

April 6, 1900.

Went to reception downtown by Epworth League. Came back with Mr. [William] Mast.

\section{April 7.}

Went down to the boys' room. Sewed white stripes on John's pants. Went to the lecture by Miss Ida Benfey. It was Les Miserables. She told it like a story. I was afraid Mr. R. would not come, but he did. I am afraid he won't ask me any more. May Bower was with Warburton.

April 9.

Went to classes this afternoon. Then to sewing this afternoon. Came home sick. My throat is so sore. Sent John over after some Listerine. He bro't it after supper. 
April 10.

Prof. Marsden's wife is Mr. Day's sister. Mr. Day's aunt married Mr. Hunter, whose first wife was Linda Neely, my father's full cousin. Mr. Day's home is in Illinois about $11 / 2$ miles from where Willie Neely lives.

\section{0}

Claude was married Aug. 28, 1900.

Aunt Ella went to Kansas, Sept. 22, 1900.

Folks came to Ames to excussion, Sept. 21.

Horace's and Olive's baby born Oct. 14.

Roy came down with typhoid fever, Oct. 13. Taken to hospital in Ag. Hall, Oct. 15. Sat up for the first time Nov. 10. Pa came Nov. 23. They went home together Nov. 23.

May was robbed Oct. 17 [of her] pocket book.

The Main burned Dec. 8, Sat. morning at 4:00 o'clock. All of North wing.

School was out Dec. 20. Got home the 21 .

\section{1}

Feb. 7.

Haley filled two front teeth with two gold fillings, guaranteed to last three years, and one silver filling, to last one year. Tooth wash Precipitate chalk and Lysterine.

Feb. 11.

Left home 6:30 this morning. Drove to Harlan in the wagon, Roy and I on the back seat, John and $\mathrm{Pa}$ in front, trunks in behind. Got to Harlan in plenty of time. Train left there about 9:30. We rode as far as Carroll. I studied my geom. most all the way. It was about twelve o'clock when we got into Carroll. It looked just as it did the night we left there last fall. John and I got over in the s.w. corner of the depot and ate a part of the lunch. Then till 3:15 or about 3:20 I put in a part of the time studying geom., and John went uptown. Guess he missed Roy to go with him. My eyes hurt, so I couldn't study much. Then we got into Ames about 6:00 o'clock, came out on the 7:30 motor.

Tuesday, Feb. 12. 
There are only a few girls here. Moved my things in No. 16, Ethel Younie's old room. Unpacked my trunk. Ethel came, stayed with me all night. Ate my first meal at the club.

Wednesday.

Took my exam in Plane. Made 2.70. Will try again Saturday. Had a letter from Mast.

Thursday.

Valentine's Day. Alice Merritt, Postmistress. I got a very lovely valentine. I think it is from J. A. Fixed up my trunk with a red cover. Looks mighty cute with my red rug. Made a sash curtain.

Saturday.

Took another exam in Plane. Flunked, of course. Will flag the whole mathematics shooting match after this. Got letters from home, from Devee Mower and one from Jim, a dandy good one.

Sunday.

Went to church. Dr. O. H. Cessna preached, text from Paul, something about take heed-I forget what it was. He didn't tell it till the end of his discourse. He read the sermon. It was a good strong sermon. Next Sunday Miles from Carroll is to preach. Dr. B. mentioned that there was a desire, I don't know from where, to dispense with mass meetings, but said that would not be so, we can not get along without them. I agree.

$$
\text { \# \# }
$$

Josephine enjoyed a happy life with her husband and three children. John, Vivian, and Richard. She was active in the church and community, and her home in Troy, New York, was a hospitable one. Trips to various locations where her husband's contracting jobs were located were pleasurable. While her parents were living, she went home every summer. After they were gone (her mother died in 1915, and her father in 1916), she and her brother John went back to Shelby for Memorial Day for many years. Josephine died July 25, 1964, a week after the death of her son Richard, and a year and three months after the death of her husband. 
May Brown had a long career of teaching and school administration. She and her brother Louis remained in the Shelby home to which William and Emma retired after they sold the farm. Horace married Olive Sutton, ran his own farm, and had one daughter. John married Helen Miller, worked for the Illinois Steel Company in Chicago, and had two children. Roy married Ruby Quisenberry, practiced engineering in Missouri, and had two children. Emma Jane, the youngest of the family, died September 6, 1970, after a career of social work in Boston-the last of this generation of Browns.

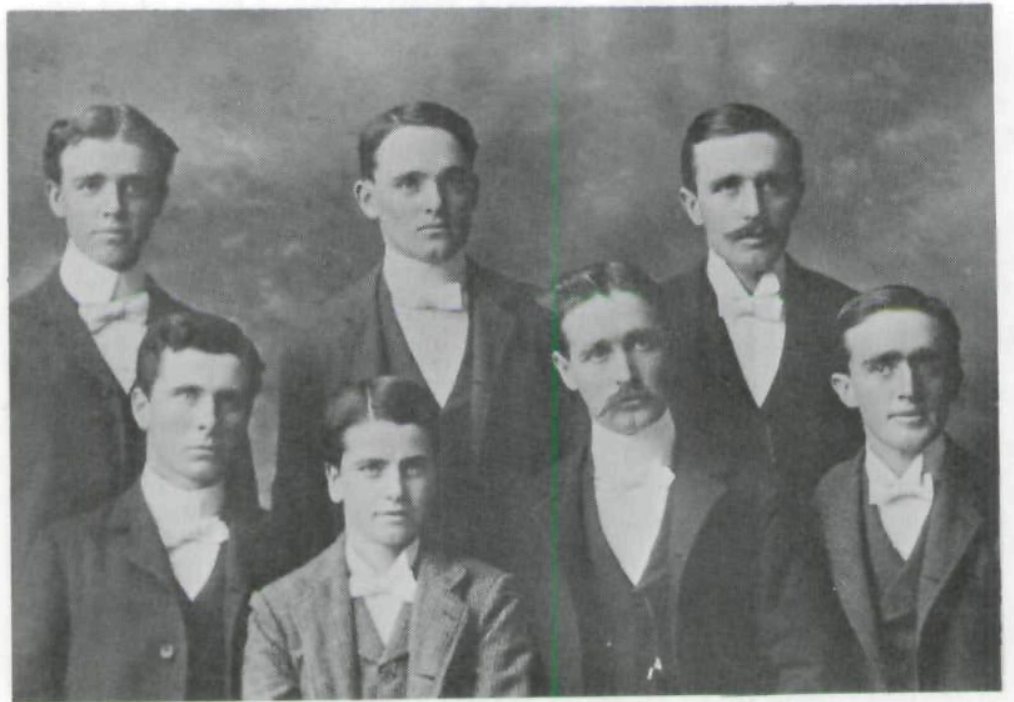

Courtesy V. Hopkins

Josephine's brothers and cousins:

Back row, left to right, Frank Leroy, John F. and Louis A; Front row, left to right, Claude, Grant, Horace H., William E. Circa 1900 
Copyright of Annals of Iowa is the property of State of Iowa, by \& through the State Historical Society of Iowa and its content may not be copied or emailed to multiple sites or posted to a listserv without the copyright holder's express written permission. However, users may print, download, or email articles for individual use. 